\title{
MEDIATION of PROFIT SHARING TO DEVELOP MSMES WITH MUDHARABAH CAPITALIZATION SCHEMES
}

\author{
Taudlikhul Afkar ${ }^{1}$, Moch. Afrizal Miradji ${ }^{2}$, Fauziyah $^{3}$ \\ Faculty of Economic and business - Universitas PGRI Adi Buana Surabaya \\ Email : afkar@unipasby.ac.id
}

\begin{abstract}
:
This study aims to show the development model of MSMEs with mudharabah capital schemes through the principle of profit sharing distribution from the perception of MSME actors. The object of research is in East Java by using a sample of three regions using random with total of 75 respondents who were obtained incidentally considering the number of MSMEs is very much. The analysis technique used is multivariate analysis using Warp PLS. The results showed that mudharabah financing with mudharabah mutlaqah, mudharabah muqayyadah and mudharabah mustyarakah financing schemes significantly influence the principle of profit sharing distribution. Furthermore, the mudharabah mutlaqah, mudharabah muqayyadah, mudharabah mustyarakah, and profit sharing distribution principles have a significant effect on the development of MSMEs. The profit sharing distribution principles can be mediated in the development of MSMEs with a capital scheme mudharabah mutlaqah, mudharabah muqayyadah, mudharabah mustyarakah. The recommended MSMEs Development Model is the Mudharabah capital scheme through the mediation of fairly in principles of profit sharing distribution.
\end{abstract}

Keywords: MSMEs development, capitalization schemes, principle of profit sharing distribution, mudharabah contract

\section{Introduction}

Micro, small, and medium enterprises (MSMEs) are currently experiencing ups and downs with the development of technology in the industry 4.0 era where there are currently many who use online media to make transactions. Micro business is currently still a concern in its development to be able to become one that increases economic growth. But there are still many problems when this MSMEs will develop, especially in capital and access to financial institutions.

The role of financial institutions in the MSMEs sector has actually been done well through conventional and sharia financial institutions which can be seen from banks, cooperation, BMTs, and other financial institutions that provide capital funds. When viewed from the Islamic banking sector the role in developing MSMEs from 2015 to 2017 shows an upward trend, namely in working capital financing 33,382 billion in 2015 and 37,868 billion in 2017.

Development of Micro, Small and Medium Enterprises (MSMEs) in Indonesia requires a conducive ecosystem to be able to grow quality. For this reason, various elements are needed to support the development of MSMEs from upstream to downstream, including products, promotions, and financing. In supporting the creation of an ecosystem conducive to the development of MSMEs, the involvement and cooperation of various parties, including Bank Indonesia is required (Bank Indonesia, 2018). 
International Journal of Economics, Business and Accounting Research (IJEBAR)

Peer Reviewed - International Journal

Vol-4, Issue-3, 2020 (IJEBAR)

E-ISSN: 2614-1280 P-ISSN 2622-4771

https://jurnal.stie-aas.ac.id/index.php/IJEBAR

Study of factors that support MSMEs development (Sakur, 2011) as seen from the use of financing, business environment conditions, implementation of strategies, and MSMEs sizes, where the results of his research show that the use of financing, business environment conditions, and MSMEs size do not affect MSMEs development, but the application of the strategy has an effect on the development of MSMEs. Therefore we need soft skills of MSMEs such as sharia marketing management (Fauzia, 2016).

The development of MSMEs (Purnamasari and Darmawan, 2017) can be done with a number of business units, employees, and financing (capital). It is also supported by Bhakti (2013) that financing with the principle of profit sharing is ideal for MSMEs, but the obstacle that is feared is the asymmetry of information that will lead to fraud. This condition is supported by the results of Afkar's study (2017) which shows that mudharabah financing has no effect on profits earned.

Lack of capital both in number and source, lack of managerial ability and operational skills in organizing and limited marketing are problems faced by MSMEs to develop their businesses (Suci, 2017). MSMEs have limitations in various ways, including limited access to market information, limited market reach, limited working networks, and limited access to strategic business locations (Tambunan, 2012). Sener and Aydun (2014) states that one of the keys to the success of a small company or MSMEs business is the role of banks in supporting funds and other services in supporting the operations of small companies or MSMEs. This condition shows a problem when MSMEs will develop their business in a better direction, coupled with the limited ability of MSMEs to provide provisions relating to capital from both conventional and Islamic financial institutions.

Actually, many capital schemes have been implemented by Islamic financial institutions, both banks and non-banks. Capital schemes conducted by Islamic banks can be done with syirkah funds through mudharabah and musyarakah. It can be done with financing provided by financial institutions such as Islamic banks or Islamic cooperation and other financial institutions. Islamic banks in providing financing one of which can be done with profit sharing through mudharabah contracts, where the development strategy for Islamic bank profit sharing also has a positive impact on increasing profitability (Afkar, 2015). Mudharabah can be divided into mudharabah mutlaqah, mudharabah muqayyadah, and mudharabah mustyarakah (Nurhayati and Wasilah, 2015).

Mudharabah financing is one of the advantages of Islamic banks compared to conventional banks because it promotes the principles of partnership and justice (Waluyo, 2015). Financing mudharabah mutlaqah can be done by giving freedom to fund managers to develop their businesses, while mudharabah muqayyadah financing puts restrictions on fund management, and mudharabah mustyarakah financing can be done with the participation of fund managers to provide capital (Nurhayati and Wasilah, 2015). The results of the study showed the inconsistency that mudharabah is an ideal funding or capital scheme but still considers the existence of information asymmetry, while for Islamic banks some studies show a significant influence through MSMEs financing that has been given. The difficulty of MSMEs capital to develop its business is interesting to study more deeply because actually banks have provided capital through a variety of profit sharing schemes.

\section{Literature Review}

\section{Problems in MSMEs Development}

The development of MSMEs requires the support of various parties who support both internal and external. The results showed that capital became one of the most dominant factors being the weaknesses of MSMEs to develop their businesses such as enlarging the scale of business, increasing income, and businesses diversification. 
International Journal of Economics, Business and Accounting Research (IJEBAR)

Peer Reviewed - International Journal

Vol-4, Issue-3, 2020 (IJEBAR)

E-ISSN: 2614-1280 P-ISSN 2622-4771

https://jurnal.stie-aas.ac.id/index.php/IJEBAR

Problems faced by MSMEs (Suhendar, 2010) explain from internal factors namely : 1) lack of capital and limited access to capital financing are the main factors needed to develop a business unit, 2) the quality of human resources both in terms of formal education and knowledge and skills, 3) weak business network and market penetration capability, 4) mentality of MSMEs entrepreneurs, namely the spirit of entrepreneurship to keep innovating, resilient without giving up, willing to sacrifice and the spirit of wanting to take risks, 5) lack of transparency so that a lot of information and networks are hidden and not notified to those who subsequently run the business so that this creates difficulties for future generations in developing their businesses.

The problems of MSMEs are seen from external factors (Suhendar, 2010) such as : 1) the business climate is not completely conducive where the government's policy to develop MSMEs, even though from year to year continues to be refined, it is felt not to be fully conducive. This can be seen, among other things, the occurrence of unfair competition between small and medium-scale entrepreneurs and large entrepreneurs, 2) limited business facilities and infrastructure such as lack of information related to the progress of science and technology, causing the facilities and infrastructure they have also not rapidly developing and not supporting the progress of their business as expected, 3) illegal levies where the practice of illegal levies or better known as illegal levies is also an obstacle for MSMEs because it adds to the expense that is not small, 4) implications of regional autonomy where sometimes enthusiasm excessive regionalism, sometimes creating unfavorable conditions for entrepreneurs outside the region to develop their businesses in the area, 5) implications of free trade where there are often issues that are unfairly used by developed countries as barriers (Non-Tariff Barrier for Trade), 6 ) characteristics of products with ket ahanan short, 7) limited market access, 8) limited access to information.

\section{MSMEs Development Strategy}

The Ministry of Cooperation and MSMEs has launched several main approaches to implementing cooperation development and MSMEs in Indonesia, namely through (Sriyana, 2010):

1. The Conducive Business Environment Development Strategy is intended to enhance the competitiveness of SMEs by creating the widest possible business opportunities, eliminating high economic costs, and ensuring a healthy market mechanism.

2. Strategies to Increase Cooperation and MSMEs Access to Productive Resources, The Ministry of Cooperation and MSMEs can encourage efforts to increase Cooperation and MSMEs access to capital and financing sources, increase market access, technology access, and information access. Considering the very large number of Cooperation and MSMEs, then for the effectiveness of Cooperation and MSMEs development is pursued through a center approach accompanied by the development of the BDS market (business development services) in Indonesia.

3. Cooperation and MSMEs Entrepreneurship and Competitiveness Development Strategy Entrepreneurship is a factor of production. For this reason, the Ministry of Cooperation and MSMEs develop policies to grow new entrepreneurs, develop incentive systems for enhancing existing Cooperation and MSMEs entrepreneurship, the development of competitive and technology-based Cooperation and MSMEs, and the development of production policies clean.

4. Strategies for Strengthening Cooperation Institutions Development of genuine cooperation is one vehicle for realizing economic democracy in Indonesia. For this reason, efforts are needed to improve the Cooperation Law, improve the administration and supervision of cooperation legal entities, provide guidance and facilities to cooperation, as well as protection of cooperation, and public protection of cooperation business activities. The 
International Journal of Economics, Business and Accounting Research (IJEBAR)

Peer Reviewed - International Journal

Vol-4, Issue-3, 2020 (IJEBAR)

E-ISSN: 2614-1280 P-ISSN 2622-4771

https://jurnal.stie-aas.ac.id/index.php/IJEBAR

strategy of strengthening the cooperation institutions is expected to be able to develop quality cooperation units and be able to provide good services to more than 20 million members.

5. Strategies for Increasing Synergy and the Role of Community Participation Synergy and community participation in economic development are an embodiment of economic democracy. The strategy to increase synergy and community participation is carried out with the approach of increasing community participation in planning, implementing and evaluating Cooperation and MSMEs development; increasing the capacity of developing institutions and the business world to participate in the development of the Cooperation and MSMEs; and MSMEs institutional development.

\section{Principles of Profit Sharing Distribution}

National Sharia Council Fatwa No. 15 / DSN-MUI / IX / 2000 Concerning the Principles of Distribution of Business Results in Sharia Financial Institutions with the consideration that the distribution of business results among the parties (partners) in a form of cooperation may be based on: 1) The principle of Profit Sharing, namely profit sharing calculated from income after deducting capital and costs, and 2) the principle of Revenue Sharing (Net Revenue Sharing), 3) revenue sharing calculated from income after deducting capital and each has advantages and disadvantages.

The fatwa explained the guidelines in the distribution of results by stipulating: 1) Basically, Islamic Financial Institutions (LKS) may use the principle of Revenue Sharing (Net Revenue Sharing) and Profit Sharing in profit sharing with their partners (customers), 2) In terms of benefit (al-ashlah), at present, the distribution of results of operations should be used the principle of Revenue Sharing (Net Revenue Sharing), 3) The determination of the principle of sharing the results of selected businesses must be agreed in the contract.

Calculation of profit sharing for Islamic banks is carried out with several stages of the process, namely:

1. Determine the principle of profit sharing that is used

The provisions of the Fatwa of the National Sharia Board make it clear that the sharing of the results of operations of Islamic banks can use Revenue Sharing or Profit Sharing. At present all Islamic banks still use revenue sharing both in sharing the results of Islamic banks as fund managers with financiers (fund raising) and Islamic banks as financiers to debtor customers (managing funds with mudharabah and musyarakah principles).

2. The principle of Revenue Sharing

In accordance with the provisions in the fatwa that what is divided in the mudharabah principle is the result of the management of the mudharabah fund, in accounting terms it is often known as gross profit, because in the mudharabah principle mudharabah capital is not permitted to be divided, sales contain mudharabah capital, so it is not permitted distributing mudharabah profit from sales (turnover). While the principle of Profit Sharing of the results of shared business is net operating income.

3. Principles for Profit (Profit Sharing)

At present there is no Islamic bank that uses the calculation of profit sharing using the profit sharing principle. In the principle of profit sharing, the revenue from operating income divided is net income, that is, the gross profit reduced by expenses related to the management of mudharabah funds. One obstacle in the principle of profit sharing is the honest, transparent and objective determination of expenses that are calculated in mudharabah. If an Islamic bank intends to apply the principle of profit sharing, two reports must be made, namely: 1) reports relating to the management of mudharabah financing, namely banks as managers, and 2) reports relating to Islamic banks as Islamic entities that manage funds and other activities. 
International Journal of Economics, Business and Accounting Research (IJEBAR)

Peer Reviewed - International Journal

Vol-4, Issue-3, 2020 (IJEBAR)

E-ISSN: 2614-1280 P-ISSN 2622-4771

https://jurnal.stie-aas.ac.id/index.php/IJEBAR

\section{Type of Mudharabah Contracts \\ Mudharabah Mutlaqah}

Mudharabah mutlaqah is a form of cooperation between the fund owner and the fund manager. Fund management in this mudharabah muthlaqah has the nature of unlimited free funds in determining what business will be carried out and how it will be implemented. The owner of the fund gives full authority to the fund manager to manage. The selection of what objects will be used as a business and how to run them will all be left to the fund manager (Nurhayati and Wasilah, 2015).

\section{Mudharabah Muqayyadah}

Mudharabah muqayyadah is a type of cooperation agreement between the fund owner and the fund manager. In this type of contract, the owner of the fund will not give full authority to the fund manager. The owner of the funds determines the business object and others, while the fund manager only runs it. Islamic Bank in this transaction will act as a liaison agent between mudharib and shahibul maal. As a liaison agent between Shahibul Maal and Mudharib, Islamic bank will benefit in the form of fees. The amount obtained by this Islamic bank is always fixed, independent of the circumstances of the business carried out whether it is a loss, or the size of the profit. These fees received must be included in the income statement as income. Surely the mudharabah muqayyadah contract is binding or also called restricted mudharabah (Nurhayati and Wasilah, 2015).

\section{Mudharabah Mustyarakah}

Mudharabah musytarakah is also much in demand by various people in running their businesses. At the beginning of the agreement to run a business the owner of the fund finances $100 \%$ of his business, while the manager is only as implementation. Businesses that are run can sometimes receive additional capital to grow. As the business progresses, if the management can invest in this business if they are interested (Nurhayati and Wasilah, 2015).

\section{Hypothesis}

Business development in the MSMEs sector requires supporting factors such as capital, products, and promotion (Bank Indonesia, 2018). Utilization of financing, conducive business environment conditions, as well as the involvement and cooperation of various parties also support the creation of MSMEs development (Sakur, 2011). The most fundamental weakness in developing MSMEs is in the capital sector where lack of capital is difficult to develop a larger business scale so that it requires easy access to capital and capital schemes that match the needs of MSMEs. Previously a simple study had been conducted with the results of the mudharabah mutlaqah influencing the development of MSMEs by mediating the principle of profit sharing distribution (Afkar, et.al, 2019).

Types of mudharabah mutlaqah, mudharabah muqayyadah, and mudharaba mustyarakah are capital schemes obtained from Islamic financing with the principle of equitable distribution of profit sharing. Mudharabah gives freedom for business managers to manage businesses according to their wishes in accordance with sharia principles (Nurhayati and Wasilah, 2015). Mudharabah muqayyadah provides limits for business managers to determine the type of business that is managed so that it is in accordance with the wishes of the capital owner. While mudharabah mustyarakah is free to determine the business also provides an opportunity for business managers to participate in investing in the business if interested (Nurhayati and Wasilah, 2015) so that with the use of this capital, MSMEs can expand their businesses by increasing their income, developing a larger business scale, and also develop businesses with various types of businesses. The mudharabah mutlaqah and mudharabah muqayyadah schemes 
International Journal of Economics, Business and Accounting Research (IJEBAR)

Peer Reviewed - International Journal

Vol-4, Issue-3, 2020 (IJEBAR)

E-ISSN: 2614-1280 P-ISSN 2622-4771

https://jurnal.stie-aas.ac.id/index.php/IJEBAR

have a role in the development of MSMEs with a fair profit sharing (Afkar et.al, 2019 and 2020).

Hypothesis 1: Principle of profit sharing distribution is influenced by the mudharabah mutlaqah, mudharabah muqayyadah, and mustyarakah mudharabah capitalizations schemes

Hypothesis 2: The development of MSMEs is influenced by mudharabah mutlaqah, mudharabah muqayyadah, and mudharabah mustyarakah capitalizations schemes

The development of MSMEs (Purnamasari and Darmawan, 2017) can be done with a number of business units, employees, and financing (capital). It is also supported by Bhakti (2013) that financing with the principle of profit sharing is ideal for MSMEs, but the obstacle that is feared is the asymmetry of information that will lead to fraud. National Sharia Council Fatwa No. 15 / DSN-MUI / IX / 2000 Concerning the Principles of Distribution of Business Results in Sharia Financial Institutions with the consideration that the distribution of business results between the parties (partners) in a form of business cooperation can be done with profit sharing or revenue sharing. The principle is in accordance with the agreement of the parties involved so that it continues to promote justice, as well as when a loss occurs, it is determined in accordance with the agreement from the beginning.

Mudharabah capital schemes provide freedom in business management and some are bound and provide opportunities to invest in joint capital. The use of the principle of profit sharing distribution will have a better impact when MSMEs develop their business in a bigger scale, increase their income, and develop a more varied type of business (Afkar et.al, 2020).

Hypothesis 3: $\quad$ Principle of profit sharing distribution is able to mediate the Development of MSMEs

Hypothesis 4: $\quad$ Recommended MSMEs development model with Mudharabah scheme through fairly in Principles of Distribution Profit Sharing

\section{Research Methods}

\section{Research Design}

This research was conducted by survey using a questionnaire to obtain data. This research approach uses quantitative structural models. To find out the appropriate model in this research, a model test was conducted. Outer models are used to test the validity and reliability of indicators and statement items in the questionnaire used. The inner model is used to determine the effect of each exogenous variable on endogenous variables including intervening variables in this study.

\section{Population and Sample}

The population in this study were all MSMEs in East Java, amounting to more than 6 million businesses. The sampling technique uses simple random. In accordance with the theme of this study is the development of MSMEs, the researchers set a sample randomly so that each region has the same opportunity to become a research sample in order to see the MSMEs development model according to respondents perceptions that have the lowest number of MSMEs, then the sample in this study can be determined as many as 3 (three) regions in East Java, namely Sidoarjo City, Madiun City, and Gresik Regency.

The calculation of the number of MSMEs respondents who are members of this sample is done by counting the number of indicators used in this study with the variables in this study, then adding them to each sample region. There are 5 (five) research variables consisting of 3 (three) exogenous variables and 2 (two) endogenous variables. Each variable has 3 (three) indicators so there are 15 (fifteen) of them. Taking respondents in this study using a simple technique by means of $5 \times 15=75$. 
International Journal of Economics, Business and Accounting Research (IJEBAR)

Peer Reviewed - International Journal

Vol-4, Issue-3, 2020 (IJEBAR)

E-ISSN: 2614-1280 P-ISSN 2622-4771

https://jurnal.stie-aas.ac.id/index.php/IJEBAR

\section{Operational Variables}

Exogenous Variables

Mudharabah Mutlaqah Capital Scheme $\left(\mathbf{X}_{1}\right)$

The mudharabah mutlaqah capital scheme is the capital provided to MSMEs with fund management carried out absolutely by the mudharib (manager or manager) while the owner of the fund does not interfere in business management. Indicators used for mudharabah mutlaqah capital are freedom in managing funds $\left(\mathrm{X}_{1.1}\right)$, freedom to determine the type of business $\left(\mathrm{X}_{1.2}\right)$, freedom of doing business $\left(\mathrm{X}_{1.3}\right)$.

\section{Mudharabah Muqayyadah Capital Scheme $\left(\mathbf{X}_{2}\right)$}

Mudharabah muqayyadah capital scheme is a capital that is given to MSMEs with the management of funds for businesses given control or restrictions by the owner of the funds (Shaibul maal). Indicators used in mudharabah muqayyadah capital are the type of business determined by the owner of the fund $\left(\mathrm{X}_{2.1}\right)$, limitation on managing funds $\left(\mathrm{X}_{2.2}\right)$, limitation in running a business / investment $\left(\mathrm{X}_{2.3}\right)$.

\section{Mudharabah Mustyarakah Capital Scheme $\left(\mathbf{X}_{3}\right)$}

Mudharabah mustyarakah capital scheme is the capital provided to MSMEs, which is initially fully funded by the Islamic Bank, then after running the fund manager provides additional capital. Indicators used in Mudharabah mustyarakah capital are agreements on changes in profit sharing $\left(X_{3.1}\right)$, joint capital payments $\left(X_{3.2}\right)$, business management agreements $\left(X_{3.3}\right)$.

\section{Intervening Variable $\left(\mathbf{Y}_{1}\right)$}

Intervening variable in this study is the Principles of Profit Sharing Distribution, the system of sharing the results of the business carried out by the business manager. Indicator The principle of profit sharing distribution using revenue sharing on the basis of Profit sharing $\left(\mathrm{Y}_{1.1}\right)$, revenue sharing $\left(\mathrm{Y}_{1.2}\right)$, Risk/Loss Sharing $\left(\mathrm{Y}_{1.3}\right)$.

\section{Endogenous Variable $\left(\mathbf{Y}_{2}\right)$}

Endogenous variables in this study are the development of MSMEs, namely the development of MSMEs that are in accordance with the scheme and access to capital in Islamic financial institutions. This MSME Floating Indicator uses Increased Income $\left(\mathrm{Y}_{2.1}\right)$, Business Scale Developtment $\left(\mathrm{Y}_{2.2}\right)$, Business Diversification $\left(\mathrm{Y}_{2.3}\right)$.

\section{Data Analysis Technique}

\section{Table 1. Outer Model}

\begin{tabular}{|c|c|c|}
\hline Convergent Validity & Discriminant Validity & Reliability \\
\hline $\begin{array}{l}\text { Convergent validity is } \\
\text { used to test the validity } \\
\text { of indicators with a } \\
\text { factor load value }>0.30 \\
\text { and a p value }<0.001 \text {. }\end{array}$ & $\begin{array}{l}\text { Discriminant validity is } \\
\text { used to test the validity of } \\
\text { the loading factor> cross } \\
\text { loading factor. }\end{array}$ & $\begin{array}{l}\text { Reliability testing uses composite reliability } \\
\text { (combined) with the condition that the } \\
\text { reliability value }>0.70 \text {, and using the internal } \\
\text { consistency reliability test with the condition } \\
\text { that the reliability value }>0.60 \text {. }\end{array}$ \\
\hline
\end{tabular}

Table 2. Inner Model

\begin{tabular}{|l|l|}
\hline \multicolumn{1}{|c|}{$\mathbf{\text { - test }}$} & \multicolumn{1}{c|}{ Goodnes of Fit } \\
\hline Hypothesis testing is done to test the & Average Path Coefficient with fit criteria $\mathrm{p}<$ \\
exogenous variables against endogenous with & 5 \\
one intervening variable. Testing is done by & Average R-Squared with fit criteria $\mathrm{p}<5$ \\
path analysis so that the t-test is used with & Average adjusted R-squared with fit criteria $\mathrm{p}$ \\
\hline
\end{tabular}


International Journal of Economics, Business and Accounting Research (IJEBAR)

Peer Reviewed - International Journal

Vol-4, Issue-3, 2020 (IJEBAR)

E-ISSN: 2614-1280 P-ISSN 2622-4771

https://jurnal.stie-aas.ac.id/index.php/IJEBAR

criteria:

p-value $<0.10$ weakly significant

p-value $<0.05$ significant

p-value $<0.01$ highly significant

Structural Equation Model is :

$Y_{1}=b_{1} X_{1}+b_{2} X_{2}+b_{3} X_{3}$

$Y_{2}=b_{1} X_{1}+b_{2} X_{2}+b_{3} X_{3}+b_{1} X_{1} * Y_{1}+b_{2} X_{2} * Y_{1}+b_{3} X_{3} * Y_{1}$

The data analysis technique used is path analysis with multivariate analysis. This analysis technique is used because to conduct an analysis of each indicator used on each variable which will then be obtained the value of the level of significance in hypothesis testing. This data analysis uses path analysis with Warp PLS (Partial Least Square) approach.

\section{Research Results and Discussions \\ Research result \\ Convergent and Discriminant Validity}

Table 3. Convergent Validity

\begin{tabular}{|l|c|c|c|c|c|c|c|c|}
\hline & $\mathrm{X} 1$ & $\mathrm{X} 2$ & $\mathrm{X} 3$ & $\mathrm{Y} 1$ & $\mathrm{Y} 2$ & $\mathrm{SE}$ & $\mathrm{p}$ value & result \\
\hline X1.1 & $(0.989)$ & 0.816 & -0.090 & 0.000 & 0.000 & 0.084 & $<0.001$ & valid \\
\hline X1.2 & $(0.705)$ & -5.290 & 0.586 & 0.000 & 0.000 & 0.104 & 0.002 & valid \\
\hline X1.3 & $(0.989)$ & 0.816 & -0.090 & 0.000 & 0.000 & 0.084 & $<0.001$ & valid \\
\hline X2.1 & 0.199 & $(0.997)$ & -0.090 & 0.000 & 0.000 & 0.084 & $<0.001$ & valid \\
\hline X2.2 & -2.448 & $(0.662)$ & 0.110 & 0.000 & 0.000 & 0.109 & 0.041 & valid \\
\hline X2.3 & 0.199 & $(0.997)$ & -0.090 & 0.000 & 0.000 & 0.084 & $<0.001$ & valid \\
\hline X3.1 & -2.448 & -2.386 & $(0.977)$ & 0.000 & 0.000 & 0.085 & $<0.001$ & valid \\
\hline X3.2 & 5.427 & -5.290 & $(0.881)$ & 0.000 & 0.000 & 0.087 & $<0.001$ & valid \\
\hline X3.3 & -2.448 & -2.386 & $(0.977)$ & 0.000 & 0.000 & 0.085 & $<0.001$ & valid \\
\hline Y1.1 & -1.488 & 1.207 & -1.259 & $(0.769)$ & 0.590 & 0.090 & $<0.001$ & valid \\
\hline Y1.2 & -2.448 & -2.386 & 1.110 & $(0.835)$ & 0.000 & 0.088 & $<0.001$ & valid \\
\hline Y1.3 & 3.530 & -3.233 & 0.045 & $(0.903)$ & -0.503 & 0.087 & $<0.001$ & valid \\
\hline Y2.1 & 0.080 & -0.609 & -0.406 & 0.451 & $(0.904)$ & 0.087 & $<0.001$ & valid \\
\hline Y2.2 & 0.199 & 0.716 & -0.090 & 0.000 & $(0.735)$ & 0.091 & $<0.001$ & valid \\
\hline Y2.3 & -0.272 & -0.060 & 0.538 & -0.506 & $(0.805)$ & 0.089 & $<0.001$ & valid \\
\hline
\end{tabular}

Source : processed by Warp PLS

Convergent validity can be seen from the value of the correlation coefficient between each indicator with exogenous and endogenous variables. If the value of the correlation coefficient (loadings factor) is greater than 0.30 then it meets the convergent validity criteria, whereas if the correlation coefficient (loadings factor) $>$ cross loading value then it can be said to meet the discriminant validity criteria. Table 1 shows that the indicators used in this study have (loadings factor) $>$ cross loading value with $p$-value $<0.10$, so it can be said to be valid.

Table 4. Discriminant Validity

\begin{tabular}{|c|c|c|c|c|c|}
\hline $\begin{array}{c}\text { Average variance } \\
\text { extract }\end{array}$ & $\mathrm{X}_{1}$ & $\mathrm{X}_{2}$ & $\mathrm{X}_{3}$ & $\mathrm{Y}_{1}$ & $\mathrm{Y}_{2}$ \\
\hline $\mathrm{X}_{1}$ & $(0.827)$ & 0.795 & 0.240 & 0.528 & 0.781 \\
\hline $\mathrm{X}_{2}$ & 0.795 & $(0.819)$ & 0.191 & 0.487 & 0.765 \\
\hline $\mathrm{X}_{3}$ & 0.240 & 0.191 & $(0.946)$ & 0.869 & 0.495 \\
\hline
\end{tabular}


International Journal of Economics, Business and Accounting Research (IJEBAR)

Peer Reviewed - International Journal

Vol-4, Issue-3, 2020 (IJEBAR)

E-ISSN: 2614-1280 P-ISSN 2622-4771

https://jurnal.stie-aas.ac.id/index.php/IJEBAR

\begin{tabular}{|c|c|c|c|c|c|}
\hline $\mathrm{Y}_{1}$ & 0.528 & 0.487 & 0.829 & $(0.838)$ & 0.555 \\
\hline $\mathrm{Y}_{2}$ & 0.781 & 0.765 & 0.495 & 0.555 & $(0.818)$ \\
\hline
\end{tabular}

Source : processed by Warp PLS

Discriminant validity can also be seen from the roots of the Average Variance Extract (AVE) and the correlation coefficient. Table 4 shows that Overall has a AVE greater than other variables so it can be said that each indicator used to measure exogenous variables, intervening variables, and endogenous variable.

\section{Reliability}

Table 5. Reliability

\begin{tabular}{|c|c|c|}
\hline Variabel & Composite Reliability & Cronbach's Alpha \\
\hline $\mathrm{X}_{1}$ & 0.846 & 0.703 \\
\hline $\mathrm{X}_{2}$ & 0.825 & 0.656 \\
\hline $\mathrm{X}_{3}$ & 0.962 & 0.940 \\
\hline $\mathrm{Y}_{1}$ & 0.875 & 0.785 \\
\hline $\mathrm{Y}_{2}$ & 0.857 & 0.748 \\
\hline
\end{tabular}

Source : processed by Warp PLS

Table 5 shows the reliability values measured by the composite and croncbach's alpha reliability. The reliability value in this study has been demonstrated by the reliability of the composite and croncbach's alpha has a variety of reliability according to the category of each value range which shows more than 0.600 so it can be concluded that the data collected is reliable and can be used for hypothesis testing.

\section{Hypothesis Test}

Inner Model

Direct Effect of Exogenous Variables and Intervening Variables to Endogenous Variables

Table 6. Hypothesis Test Result

\begin{tabular}{|c|c|c|c|c|c|c|c|}
\hline \multirow{3}{*}{ Number } & \multicolumn{2}{|c|}{ Variables } & \multicolumn{2}{c|}{ Coefficient } & \multicolumn{2}{c|}{ p-value } & \multirow{2}{*}{ Justification } \\
\cline { 2 - 7 } & Exogenous & Endogenous & $\begin{array}{c}\text { real } \\
\text { count }\end{array}$ & view & $\begin{array}{c}\text { real } \\
\text { count }\end{array}$ & view & \\
\hline 1 & $\mathrm{X}_{1}$ & $\mathrm{Y}_{1}$ & 0.422 & 0.42 & $<0.001$ & $\mathrm{p}<0.01$ & highly significant \\
\hline 2 & $\mathrm{X}_{2}$ & $\mathrm{Y}_{1}$ & -0.425 & -0.42 & $<0.001$ & $\mathrm{p}<0.01$ & highly significant \\
\hline 3 & $\mathrm{X}_{3}$ & $\mathrm{Y}_{1}$ & 0.959 & 0.96 & $<0.001$ & $\mathrm{p}<0.01$ & highly significant \\
\hline 4 & $\mathrm{X}_{1}$ & $\mathrm{Y}_{2}$ & -1.267 & -1.27 & $<0.001$ & $\mathrm{p}<0.01$ & highly significant \\
\hline 5 & $\mathrm{X}_{2}$ & $\mathrm{Y}_{2}$ & 2.090 & 2.09 & $<0.001$ & $\mathrm{p}<0.01$ & highly significant \\
\hline 6 & $\mathrm{X}_{3}$ & $\mathrm{Y}_{2}$ & -0.146 & -0.15 & 0.093 & $\mathrm{p}=0.09$ & weakly significant \\
\hline 7 & $\mathrm{Y}_{1}$ & $\mathrm{Y}_{2}$ & -0.237 & -0.24 & 0.015 & $\mathrm{p}=0.01$ & highly significant \\
\hline
\end{tabular}

Source : processed by Warp PLS

Number 1 shows the financing of the mudharabah mutlaqah capitalization scheme $\left(\mathrm{X}_{1}\right)$ affects to the Principles of Profit Sharing Distribution $\left(\mathrm{Y}_{1}\right)$. Its means that with the freedom in managing funds, the freedom to determine the type of business, the freedom to run a business is able to have a significant influence on the distribution of profits from revenue and net profits, as well as the distribution of risk within the principle of profit sharing distribution.

Number 2 shows that mudharabah muqayyadah capitalization scheme $\left(\mathrm{X}_{2}\right)$ affects to the Principles of Profit Sharing Distribution $\left(\mathrm{Y}_{1}\right)$. Its means that with the type of business determined by the owner of the fund, there are limits in the management of funds, there are limitations in running a business or investment able to have a significant influence on the 
International Journal of Economics, Business and Accounting Research (IJEBAR)

Peer Reviewed - International Journal

Vol-4, Issue-3, 2020 (IJEBAR)

E-ISSN: 2614-1280 P-ISSN 2622-4771

https://jurnal.stie-aas.ac.id/index.php/IJEBAR

distribution of profits from revenue or net profits, as well as the distribution of risk in the principle of profit sharing distribution.

Number 3 shows that mudharabah mustyarakah capitalization scheme $\left(\mathrm{X}_{3}\right)$ affects to the Principles of Profit Sharing Distribution ( $\left.\mathrm{Y}_{1}\right)$. Its means that the Agreement on changes in profit sharing, joint capital payments, and business management agreements are able to have a significant influence on the distribution of profits from revenue and net profits, as well as risk sharing in the principle of profit sharing distribution.

Number 4 shows that the financing of mudharabah mutlaqah capitalization scheme $\left(\mathrm{X}_{1}\right)$ affects to the development of MSMEs $\left(\mathrm{Y}_{2}\right)$. Its means that with the freedom in managing funds, the freedom to determine the type of business, the freedom to run a business is able to have a significant influence on the Increased Income, Business Scale, and Business Diversification in the development of MSMEs.

Number 5 shows that mudharabah muqayyadah capitalization scheme $\left(\mathrm{X}_{2}\right)$ affects to the development of MSMEs $\left(\mathrm{Y}_{2}\right)$. Its means that with the freedom in managing funds, the freedom to determine the type of business, the freedom to run a business is able to have a significant influence on the Increased Income, Business Scale, and Business Diversification in the development of MSMEs.

Number 6 Shows that the mudharabah mustyarakah capitalization scheme $\left(\mathrm{X}_{3}\right)$ affects to the development of MSMEs $\left(\mathrm{Y}_{2}\right)$. Its means that with the freedom in managing funds, the freedom to determine the type of business, the freedom to run a business is able to have a significant influence on the Increased Income, Business Scale, and Business Diversification in the development of MSMEs.

Number 7 shows that the Principle of Profit Sharing Distribution $\left(\mathrm{Y}_{1}\right)$ affects to the development of MSMEs $\left(\mathrm{Y}_{2}\right)$. Its means that the distribution of profits from revenue and net profits, as well as risk sharing within the principle of profit sharing distribution can have a significant effect on Increased Income, business scale, and business diversification in the development of MSMEs.

Indirect Effect of Exogenous Variables through Intervening Variables to Endogenous Variables

Table 7. Indirect Effects

\begin{tabular}{|c|c|c|c|c|c|c|c|c|c|c|c|}
\hline \multicolumn{6}{|c|}{ Indirect effects for paths with 2 segments } & \multicolumn{6}{|c|}{$\begin{array}{c}\text { p-values of indirect effects for paths with } 2 \\
\text { segments }\end{array}$} \\
\hline & $\mathrm{X}_{1}$ & $\mathrm{X}_{2}$ & $X_{3}$ & $\mathrm{Y}_{1}$ & $\mathrm{Y}_{2}$ & & $\mathrm{X}_{1}$ & $\mathrm{X}_{2}$ & $\mathrm{X}_{3}$ & $\mathrm{Y}_{1}$ & $\mathrm{Y}_{2}$ \\
\hline $\mathrm{X}_{1}$ & & & & & & $X_{1}$ & & & & & \\
\hline $\mathrm{X}_{2}$ & & & & & & $\mathrm{X}_{2}$ & & & & & \\
\hline $\mathrm{X}_{3}$ & & & & & & $\mathrm{X}_{3}$ & & & & & \\
\hline $\mathrm{Y}_{1}$ & & & & & & $\mathrm{Y}_{1}$ & & & & & \\
\hline $\mathrm{Y}_{2}$ & $-\overline{1}$ & 0.101 & $-\overline{2}$ & & & $\mathrm{Y}_{2}$ & 0.100 & 0.100 & 0.002 & & \\
\hline
\end{tabular}

Sources : processed by Warp PLS

Table 7 shows that mudharabah mutlaqah capitalization scheme $\left(\mathrm{X}_{1}\right)$, mudharabah muqayyadah capitalization scheme $\left(\mathrm{X}_{2}\right)$ mudharabah mustyarakah capitalization scheme $\left(\mathrm{X}_{3}\right)$ indirectly affect the development of MSMEs $\left(\mathrm{Y}_{2}\right)$ through the mediation by principle of profit sharing distribution $\left(\mathrm{Y}_{1}\right)$. However, the one with the highest affect is mudharabah mustyarakah capitalization scheme $\left(\mathrm{X}_{3}\right)$ Financing with p-value 0.002 .

Total Effects Contribution of Exogenous Variables through Intervening Variables to Endogenous Variables

Table 8. Total Effects 
International Journal of Economics, Business and Accounting Research (IJEBAR)

Peer Reviewed - International Journal

Vol-4, Issue-3, 2020 (IJEBAR)

E-ISSN: 2614-1280 P-ISSN 2622-4771

https://jurnal.stie-aas.ac.id/index.php/IJEBAR

\begin{tabular}{|c|c|c|c|c|c|c|c|c|c|c|c|}
\hline \multicolumn{9}{|c|}{ Total effects } & \multicolumn{7}{c|}{ P values for total effects } \\
\hline & $\mathrm{X}_{1}$ & $\mathrm{X}_{2}$ & $\mathrm{X}_{3}$ & $\mathrm{Y}_{1}$ & $\mathrm{Y}_{2}$ & & $\mathrm{X}_{1}$ & $\mathrm{X}_{2}$ & $\mathrm{X}_{3}$ & $\mathrm{Y}_{1}$ & $\mathrm{Y}_{2}$ \\
\hline $\mathrm{X}_{1}$ & & & & & & $\mathrm{X}_{1}$ & & & & & \\
\hline $\mathrm{X}_{2}$ & & & & & & $\mathrm{X}_{2}$ & & & & & \\
\hline $\mathrm{X}_{3}$ & & & & & & $\mathrm{X}_{3}$ & & & & & \\
\hline $\mathrm{Y}_{1}$ & 0.422 & - & 0.959 & & & $\mathrm{Y}_{1}$ & $<0.001$ & $<0.001$ & $<0.001$ & & \\
\hline $\mathrm{Y}_{2}$ & - & 2.191 & - & - & & $\mathrm{Y}_{2}$ & $<0.001$ & $<0.001$ & $<0.001$ & 0.015 & \\
\hline
\end{tabular}

Sources : processed by Warp PLS

Table 8 shows that each exogenous variable influences endogenous variables with highly significant level of $\mathrm{p}$-value. It means that all variables used in this study have a contribution.

Table 9. Absolute Contribution

\begin{tabular}{|c|c|r|c|c|}
\hline $\begin{array}{c}\text { Absolute } \\
\text { Contribution }\end{array}$ & $\begin{array}{c}\text { Total } \\
\text { Effects }\end{array}$ & squared & $\%$ & $\begin{array}{c}\text { Contribution } \\
\%\end{array}$ \\
\hline $\mathrm{X}_{1}$ to $\mathrm{Y}_{1}$ & 0,422 & 0,178 & $100 \%$ & 0,18 \\
\hline $\mathrm{X}_{2}$ to $\mathrm{Y}_{1}$ & $-0,425$ & 0,181 & $100 \%$ & 0,18 \\
\hline $\mathrm{X}_{3}$ to $\mathrm{Y}_{1}$ & 0,959 & 0,920 & $100 \%$ & 0,92 \\
\hline $\mathrm{X}_{1}$ to $\mathrm{Y}_{2}$ & $-1,367$ & 1,869 & $100 \%$ & 1,87 \\
\hline $\mathrm{X}_{2}$ to $\mathrm{Y}_{2}$ & 2,191 & 4,800 & $100 \%$ & 4,80 \\
\hline $\mathrm{X}_{3}$ to $\mathrm{Y}_{2}$ & $-0,373$ & 0,139 & $100 \%$ & 0,14 \\
\hline $\mathrm{Y}_{1}$ to $\mathrm{Y}_{2}$ & $-0,237$ & 0,056 & $100 \%$ & 0,06 \\
\hline
\end{tabular}

Sources : processed by Warp PLS

Table 9 shows the absolute contribution to each variable indicating that the mudharabah mustyarakah capitalization scheme $\left(\mathrm{X}_{3}\right)$ has a greater contribution to the principle of profit sharing distribution $\left(\mathrm{Y}_{1}\right)$ which is greater than the other variables that is equal to $0.92 \%$. However, the larger one that has contributed to the development of MSMEs $\left(\mathrm{Y}_{2}\right)$ is mudharabah muqayyadah capitalization scheme $\left(\mathrm{X}_{2}\right)$ with a contribution value of $4.80 \%$.

\section{Inner Model}

Table 10. Goodness of Fit Inner Model

\begin{tabular}{|r|l|c|c|c|}
\hline \multicolumn{1}{|c|}{ No } & \multicolumn{1}{|c|}{$\begin{array}{c}\text { Fit Model and Quality } \\
\text { Indices }\end{array}$} & Fit Criteria & result & Justification \\
\hline 1 & $\begin{array}{l}\text { Average Path Coefficient } \\
\text { (APC) }\end{array}$ & $\mathrm{p}<0.05$ & $0.792, \mathrm{p}<0.001$ & good \\
\hline 2 & Average R-squared (ARS) & $\mathrm{p}<0.05$ & $0.704, \mathrm{p}<0.001$ & good \\
\hline 3 & Average Adjusted R-squared & $\mathrm{p}<0.05$ & $0.688, \mathrm{p}<0.001$ & good \\
\hline 5 & Average block VIF (AVIF) & $\begin{array}{c}\text { Acceptable if } \\
\leq 5, \text { ideally } \leq \\
3.30\end{array}$ & 4.506 & accepted \\
\hline 5 & $\begin{array}{l}\text { Average full colliniearity VIF } \\
\text { AFVIF) }\end{array}$ & $\begin{array}{c}\leq 5, \text { ideally } \leq \\
3.30\end{array}$ & 5.000 & accepted \\
\hline
\end{tabular}

Sources : processed by Warp PLS

Table 10 shows the average path coefficient (APC) or the average path coefficient of 0.792 with a significance level of $\mathrm{p}$-value $<0.001$, meaning that the coefficient on each path has a significant influence of exogenous variables on endogenous variables and also mediation models of endogenous variables. Average R-squared (ARS) shows 0.704 with p-value $<0.001$ 
International Journal of Economics, Business and Accounting Research (IJEBAR)

Peer Reviewed - International Journal

Vol-4, Issue-3, 2020 (IJEBAR)

E-ISSN: 2614-1280 P-ISSN 2622-4771

https://jurnal.stie-aas.ac.id/index.php/IJEBAR

and Average Adjusted R-squared of $0.688 \mathrm{p}$-value $\mathrm{p}<0.001$ means that it shows a significant $68.80 \%$ influence of exogenous variables on endogenous variables through mediation. While the remaining $31.20 \%$ is influenced by other variables not used in this study. Average block VIF (AVIF) value of $2,256<4,506<5,000$ including the ideal category and the Average Full Colliniearity VIF (AFVIF) value of 3,300 $<5,000 \leq 5,000$ included in the accepted condition. This means that the results of this analysis indicate that each variable in this study is free from multicollinearity. Free from multicollinearity shows that each variable is not interconnected or does not have a significant correlation so that each variable used in this study is independent or mutually independent.

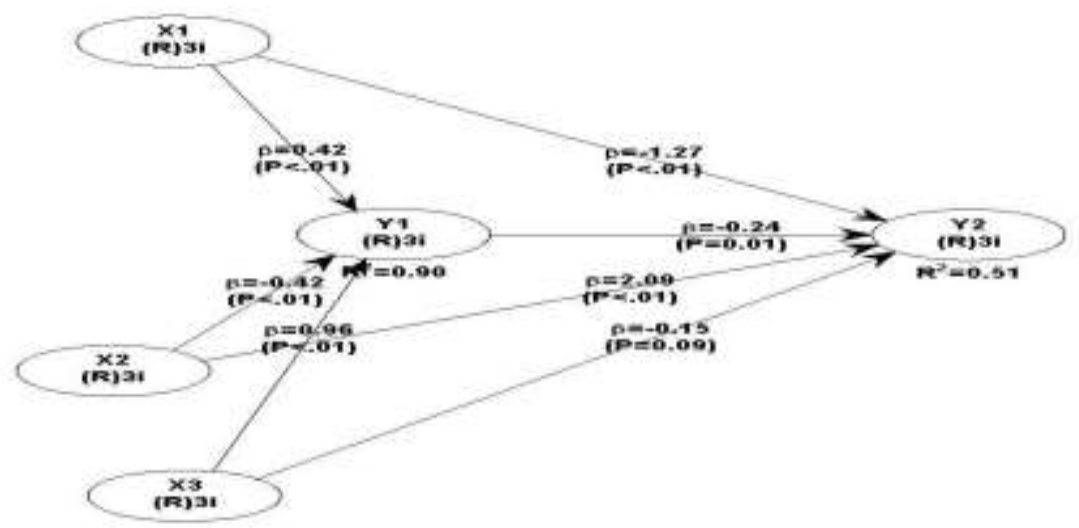

Figure 1. Model of Research Findings

Figure 1 shows the MSMEs development model recommended in this study through the mediation by principle of profit sharing distribution with the Mudharabah Mutlaqah, Mudharabah Muqayyadah, and Mudharabah Mustyarakah capital schemes. The structural equations obtained in this study are as follows:

$\mathrm{Y} 1=0.42 \mathrm{X}_{1}-0.42 \mathrm{X}_{2}+0.96 \mathrm{X}_{3}$

$\mathrm{Y} 2=-1.27 \mathrm{X}_{1}+2.09 \mathrm{X}_{2}-0.15 \mathrm{X}_{3}-0.100 \mathrm{X}_{1} * \mathrm{Y}_{1}+0.101 \mathrm{X}_{2} * \mathrm{Y}_{1}-0.227 \mathrm{X}_{3} * \mathrm{Y}_{1}$

\section{Discussions}

Principle of Profit Sharing Distribution is influenced by the Mudharabah Mutlaqah, Mudharabah Muqayyadah, and Mudharabah Mustyarakah Capitalization Schemes

Capital needs in a business is one component that cannot be separated when wanting to increase its business to be bigger. Capital requirements for micro, small and medium entrepreneurs must also be balanced with ease in obtaining access to the capital and provide facilities in various conditions so that micro, small and medium entrepreneurs can strengthen their capital well.

The principle of profit sharing distribution in an Islamic business scheme actually provides an opportunity for the parties involved in determining the profit sharing ratio through agreement. In principle, in sharia business investment it is recommended to share profits and risks to avoid usury. Profit sharing can be done from net profit or gross profit, while the division of risk of loss can be done by net loss.

The results of this study indicate that business managers in this case are the owners of MSMEs with the freedom to determine the business, the freedom to manage business finances has an influence on the principle of profit sharing distribution, as well as the limitations in managing the business, the limits in the type of business being managed also provide influence 
International Journal of Economics, Business and Accounting Research (IJEBAR)

Peer Reviewed - International Journal

Vol-4, Issue-3, 2020 (IJEBAR)

E-ISSN: 2614-1280 P-ISSN 2622-4771

https://jurnal.stie-aas.ac.id/index.php/IJEBAR

on the principle of profit sharing distribution. It can be concluded that with the mudharabah muqayyadah and mudharabah mutlaqah capiatlization schemes from the perceptions of MSMEs managers contributing to the distribution of profit sharing related to business investment. While the perception of MSMEs managers when given the opportunity to have a mutual business through the mudharabah mustyarakah scheme also has a positive impact on principle of profit sharing distribution. It means that MSMEs managers do not object to joint business ownership.

\section{Development of MSMEs is influenced by Mudharabah Mutlaqah, Mudharabah Muqayyadah, Mudharabah Mustyarakah Capitalization Schemes, and Principles of Profit Sharing Distribution}

The development of MSMEs is an effort to improve business management in the form of income, business scale, and business expansion with various types of businesses or products sold. One of the ways to develop MSMEs is to provide sufficient capital (Purnamasari and Darmawan, 2017) this is supported by the lack of capital both in number and source, lack of managerial skills and operating skills in organizing and limited marketing is a problem faced by MSMEs to develop their businesses (Khan and Khalique, 2014).

The development of MSMEs (Purnamasari and Darmawan, 2017) can be done with a number of business units, employees, and financing (capital). It is also supported by Bhakti (2013) that financing with the principle of profit sharing is ideal for MSMEs, but the obstacle that is feared is the asymmetry of information that will lead to fraud. This condition is supported by the results of Afkar's research (2017) which shows that mudharabah financing has no effect on the profits earned.

Lack of capital both in number and source, lack of managerial ability and operational skills in organizing and limited marketing are problems faced by MSMEs to develop their businesses (Suci, 2017). MSMEs have limitations in various ways, including limited access to market information, limited market reach, limited working networks, and limited access to strategic business locations (Tambunan, 2012). Sener and Aydun (2014) states that one of the keys to the success of a small company or MSME business is the role of banks in supporting funds and other services in supporting the operations of small companies or MSMEs.

The principle of the distribution of results that prioritizes the distribution of profits and losses with agreement gives the perception of MSMEs managers to understand the need for togetherness in the form of business cooperation and financing that gives freedom in managing business, finance, and others, besides that there are limitations in managing businesses in Islamic principles do not make problems in carrying it out. The results of this study indicate that the management of MSMEs will be able to expand their business when there is capital assistance that can be absolutely independently managed or there are restrictions in the positive sense and also the participation in business ownership through shirka funds.

The principle of profit sharing distribution is able to mediate the Development of MSMEs The role of MSMEs in the economy in several studies shows a positive trend in increasing national income. This is inseparable from the role of the government which provides motivation and encouragement for the advancement of MSMEs in Indonesia. Besides that, it is also supported by the role of financial institutions as intermediaries in providing financing as venture capital to develop their businesses to become bigger.

The concept in sharia business puts forward the values of togetherness and justice. Business management with sharia principles provides an illustration that the public has a perception in the form of business development through sharia products found in Islamic 
International Journal of Economics, Business and Accounting Research (IJEBAR)

Peer Reviewed - International Journal

Vol-4, Issue-3, 2020 (IJEBAR)

E-ISSN: 2614-1280 P-ISSN 2622-4771

https://jurnal.stie-aas.ac.id/index.php/IJEBAR

financial institutions. The development of MSMEs with indicators of increasing income, a larger business scale, and the diversification of businesses and products are one of the objectives in increasing the role of MSMEs in the national economy. Various kinds of problems in developing MSMEs such as difficulties in capital, managerial skills, and marketing are a concern in economic activities.

Problems in the development of MSMEs in East Java in this study try to see from the perception of MSMEs actors related to the existence of Islamic financial institutions in their role as intermediary institutions. Islamic financial institutions have profit-sharing products based on the principle of profit-sharing distribution. This research shows that the development of MSMEs with the mediation principle of profit sharing distribution can be done, where there is a risk sharing and profit sharing done by contract so that no one party is harmed because it has been agreed since the beginning.

Mudharabah capital schemes that are carried out with mudharabah mutlaqah, mudharabah muqayyadah, and mudharabah mustyarakah provide a positive influence on the development of MSMEs according to the public perception as MSMEs actors with the mediation of the principle of profit sharing distribution. It shows that the actual development of MSMEs in East Java can be done with a mudharabah capital scheme by mediating the principle of profit sharing distribution. This means that the form of capital is able to motivate the development of MSMEs that are suitable for the East Java region with the mudharabah model with the mediation principle of profit sharing distribution.

\section{The recommended MSMEs Development model}

The MSMEs development model in several studies shows that there is a need for capital assistance so that MSMEs entrepreneurs can develop their businesses to become bigger. It's just necessary to pay attention to the perception of MSMEs directly not only from the side of financial institutions that provide capital assistance through financing products.

Government programs in developing MSMEs need to be carried out from upstream to downstream with the help of all parties so that MSMEs with diverse types of businesses can have a role in the national economy. The program becomes more interesting when viewed from the side of MSMEs directly so that problems and solutions offered in the development of MSMEs will be known.

This research sees from the side of MSME actors for the development of better MSMEs. The results of this study indicate that in developing MSMEs through capital, it is carried out with a mudharabah capital model with the mediation of the principle of profit sharing distribution. This means that with mudharabah capital, MSMEs can run their business with full capital from the owner of the funds or by way of mutual cooperation to deposit capital until togetherness in business ownership.

This research shows the development model of MSMEs in East Java with a mudharabah capital scheme through the mediation by principle of profit sharing distribution. The MSMEs development model according to the results of this study is an ideal result where it is already considered from the perspective of MSME actors to provide their perceptions regarding appropriate capital schemes to develop MSMEs for the better. However, it does not rule out the possibility that the results of this study will require deeper study because of limitations.

\section{Conclusions}

1. Capital schemes of mudharabah mutlaqah, mudharabah muqayyadah, and mudharabah mustyarakah affect the principle of profit sharing distribution. It means that the distribution of profit sharing with the distribution of profits and risk sharing according to MSME actors' perceptions is influenced by freedom in managing the business absolutely and when there 
International Journal of Economics, Business and Accounting Research (IJEBAR)

Peer Reviewed - International Journal

Vol-4, Issue-3, 2020 (IJEBAR)

E-ISSN: 2614-1280 P-ISSN 2622-4771

https://jurnal.stie-aas.ac.id/index.php/IJEBAR

are restrictions in managing the business, in addition also when there is cooperation in business ownership with each actor depositing capital namely between SMEs and Islamic financial institutions. Therefore, the mudharabah capital scheme in its application needs to pay attention to the perceptions of MSMEs actors to find out the suitability in the distribution of capital assistance so that a fair distribution of profit sharing will be created.

2. The development of MSMEs can be carried out with the mudharabah mutlaqah, mudharabah muqayyadah, mudharabah mustyarakah, and principles of profit sharing distribution. The development of MSMEs can be done with the freedom to determine the form of business but still based on sharia, but it can also be done when the MSMEs actors are given restrictions in managing their business with certain considerations in accordance with sharia. Cooperation in business ownership is also one factor that can develop MSMEs. Furthermore, the existence of the principle of distribution of results provides clarity and fairness in the distribution of business risks and business profits so that no one party is harmed.

3. The principle of the distribution of revenue sharing is able to mediate in the development of MSMEs with the mudharabah mutlaqah, mudharabah muqayyadah, and mudharabah mustyarakah capital schemes, thus profit sharing and risk sharing become a mediating tool for MSMEs development with the mudharabah capital scheme.

4. The recommended MSMEs development model in this research is a mudharabah capital scheme with mediation principle of profit sharing distribution. The principle of profit sharing distribution is able to provide opportunities to manage the business absolutely by MSMEs as well as with restrictions by the capital owners, as well as cooperation in managing the business.

\section{References}

Afkar, Taudlikhul. 2015. Financing Mechanism of Islamic Banking. The International Journal of Social Science. Vol. 32 No. 1, pp 1-13, E-ISSN 2305-4557 Maret 2015

Afkar, Taudlikhul. 2017. Influence Analysis Of Mudharabah Financing And Qardh Financing To The Profitability Of Islamic Banking In Indonesia. AJIE - Asian Journal of Innovation and Entrepreneurship, 2(3), 340-351.

Afkar, Taudlikhul., Utomo, Sigit Prihanto., Miradji, Moh. Afrizal., Hariawan, Ferry. 2019. The Role Of Mudharabah Mutlaqah Capital Financing And The Principle Of Profit Sharing Distribution In The Development Of MSMEs. Proceeding International Conference of Economics and Business Adi Buana (ICEBA). "Digital Transformation In Economics, Business And Management Towards Industry 4.0" Surabaya, Indonesia, $10^{\text {th }}$ August, 2019

Afkar, Taudlikhul., Utomo, Sigit Prihanto, Miradji, Moch Afrizal., Hariawan, Ferry. 2020. The Role Of Profit-Loss Sharing In Development of MSMEs. International Journal of Economics, Business and Accounting Research (IJEBAR). Vol-4, Issue-1, 2020. Pp 173184. E-ISSN: 2614-1280 P-ISSN 2622-4771. DOI : 10.29040/ijebar.v4i01.944

Bank Indonesia. 2018. Pengembangan UMKM Membutuhkan Ekosistem yang Kondusif. Seminar nasional : menciptakan Ekosistem untuk mendukung UMKM Tumbuh dan Naik Kelas. 18 Desember 2018

Bhakti, Rizki Tri Anugrah. 2013. Pemberdayaan UMKM Melalui Pembiayaan Dengan Prinsip Bagi Hasil Oleh Lembaga Keuangan Syariah. Arena Hukum Volume 6, Nomor 1, April 2013, Halaman 1-151

Fauzia, Ika Yunia. 2016. Pengembangan Softskill Dalam Bisnis Syariah Bagi Pelaku Usaha Mikro, Kecil Dan Menengah (UMKM). Proceedings Of The International Conference On University-Community Engagement Surabaya - Indonesia, 2 - 5 August 2016. Hal 881896 
International Journal of Economics, Business and Accounting Research (IJEBAR)

Peer Reviewed - International Journal

Vol-4, Issue-3, 2020 (IJEBAR)

E-ISSN: 2614-1280 P-ISSN 2622-4771

https://jurnal.stie-aas.ac.id/index.php/IJEBAR

Khan, M. W. J., and Khalique, M. 2014. An Overview of Small and Medium Enterprises in Malaysia and Pakistan: Past, Present and Future Scenario. Business and Management Horizons, 2(2):38

Nurhayati, Sri dan Wasilah. 2015. Akuntansi Syariah Di Indonesia. Jakarta : Selemba Empat.

Purnamasari, Femei Dan Darmawan, Arif. 2017. Islamic Banking And Empowerment Of Small Medium Enterprise. Etikonomi Volume 16 (2), Oktober 2017 P-Issn: 1412-8969; E-Issn: 2461-0771 Page 221 - 230 http://journal.uinjkt.ac.id/index.php/etikonomi DOI: 10.15408/etk.v16i2.5355 221

Sakur. 2011. Kajian Faktor-Faktor Yang Mendukung Pengembangan Usaha Mikrokecil Dan Menengah: Studi Kasus Di Kota Surakart. Spirit Publik. Volume 7, Nomor 2, Halaman: 85 - 110, Issn. 1907 - 0489

Sener, S., Savrul, M. and Aydun, O. 2014. Structure of Small and Medium-Sized Enterprises in Turkey and Global Competitiveness Strategies. Procedia-Social and Behavioral Sciences. 150 (2014): 212-221

Solimun., Fernandes, Adji Achmad Rinaldo., dan Nurjannah. 2017. Metode Statistika Multivariat : Pemodelan Persamaan Struktural (SEM) Pendekatan WarpPLS. Malang : UB Press

Sriyana, Jaka. 2010. Strategi Pengembangan Usaha Kecil Dan Menengah (UMKM): Studi Kasus Di Kabupaten Bantul Paper pada Simposium Nasional 2010: Menuju Purworejo Dinamis dan Kreatif

Suci, Yuli Rahmini. 2017. Perkembangan UMKM (Usaha Mikro Kecil Dan Menengah) Di Indonesia. Jurnal Ilmiah Cano Ekonomos. Vol. 6 No. 1 Januari 2017 Hal 51-58

Suhendar, Sulaeman. 2010. Pengembangan Usaha Kecil Dan Menengah Dalam Menghadapi Pasar Regional Dan Global. Infokop Nomor 25 Tahun XX.

Tambunan, Tulus. 2012. Usaha Mikro Kecil dan Menengah di Indonesia: Isu-Isu Penting. LP3ES

Waluyo, Bambang. 2015. Implementasi Mudharabah pada Pembiayaan di Bank Syariah. Jurnal Akuntansi. Politeknik Negeri Jakarta. 2015. 